\title{
Utility of Blood Cultures in Healthy Children with a History of Fever Presenting to the Emergency Department: A Comparison of Afebrile Versus Febrile on Presentation
}

\author{
Acil Servise Başvuran ve Ateş Öyküsü Olan Sağ|ıklı Çocuklarda Kan Kültürlerinin \\ Kullanılırlığının Değerlendirilmesi: Başvuruda Febril ve Afebril Durumun Karşılaştırması
}

\author{
(1) Jeannette Dodson, (1) Mohamed Badawy, (1) Erin McElvania Tekippe, (1) Halim Hennes \\ University of Texas Southwestern Faculty of Medicine, Department of Pediatrics, Division of Pediatric Emergency Medicine, Texas, USA
}

\section{Abstract}

Introduction: Blood cultures are often obtained from healthy paediatric patients with fever on presentation to the emergency department (ED). Although published guidelines and previous research outlined indications for obtaining blood culture and the relatively low risk of bacteraemia in vaccinated children, there may be practice variability among institutions and physicians. Primary objective: To describe the demographic characteristics, diagnosis, disposition and outcome of children who are fully vaccinated, healthy and have fever from whom bacterial blood cultures were obtained. Secondary objective: To determine the rate of blood culture contamination and outcomes.

Methods: Retrospective chart review of all blood cultures collected in the ED between January 1, 2015, and December 31, 2015. Patients aged 6 months to 17 years were eligible for enrolment. Children not fully vaccinated, immunocompromised or with chronic, debilitating disease were excluded. Patients were divided into febrile and afebrile cohorts based on the initial temperature at ED presentation. Data were analysed with two-sample t-test and chisquared analysis.

Results: Blood cultures were obtained from 7.980 children at the ED, with an overall positivity rate of $5.51 \%$. No significant difference was detected in the number of positive blood cultures between the two cohorts $(p=0.85)$. No significant difference was found between pathogenic cultures between the two cohorts $(p=0.35)$. All patients who were discharged with a positive blood culture were called back for a repeat culture. None grew a pathogenic organism on the repeat culture. The overall positive blood culture rate for true pathogens was $1.3 \%$, and the overall contamination rate was $1.9 \%$.

\section{Öz}

Giriş: Acil serviste (AS) değerlendirilen sağlıklı, febril çocuk hastalardan kan kültürleri genellikle alınmaktadır. Yayınlanmış kılavuzlar ve önceki araştırmalarda, kan kültürü almak için endikasyonlar ve aşılanmış çocuklarda nispeten düşük bakteremi riskinin özetlenmesine rağmen, kurumlar ve doktorlar arasında uygulama farklıııları olabilir. Bakteriyel kan kültürlerinin alındığı tam aşılanmış, sağlıklı çocuk febril hastaların demografik özelliklerini, tanısını, eğilimini ve sonuçlarını açıklamaktır. Kan kültürü kontaminasyon oranını ve sonuçlarını belirlemektir.

Yöntemler: 1 Ocak-31 Aralık 2015 tarihleri arasında AS'de toplanan tüm kan kültürlerinin çizelgesi geriye dönük olarak incelendi. Altı aydan 17 yaşına kadar olan hastalar çalışmaya dahil etmek için uygun bulundu. Tam olarak aşılanmamış, immünokompromize veya süreğen, zayıflatıcı hastalığı olan çocuklar çalışma dışı bırakıldılar. Hastalar AS'ye başvuruda ölçülen ilk sıcaklıklarına göre febril ve afebril kohortlara ayrıldılar. Veriler iki örneklemli t-testi ve ki-kare analizi ile değerlendirildi.

Bulgular: Acil servisimizde genel pozitiflik oranı \%5,51 olan 7,980 çocuğun kan kültürü vardı. İki kohort arasında pozitif kan kültürü sayısında anlamlı bir fark tespit edilmedi $(p=0,85)$. Iki kohort arasında patojenik kültürler açısından önemli bir fark bulunmadı $(p=0,35)$. Pozitif kan kültürü ile taburcu edilen tüm hastalar tekrar kültür alınması için geri çağrıldı. Hiçbirinde patojenik organizma tekrar kültürü gelişmedi. Gerçek patojenler için genel pozitif kan kültürü oranı \%1,3 idi ve genel kontaminasyon oranı \%1,9 idi.

Sonuç: Acil servise başvuran febril ve afebril sağlıklı çocuklar arasında pozitif kan kültürü oranı benzerdi. Genel pozitif kültür oranı, daha önce bildirilen bakteremi oranlarıyla tutarlı olarak düşük kalırken,

Address for Correspondence/Yazışma Adresi: Jeannette Dodson, University of Texas Southwestern Faculty of Medicine, Department of Pediatrics, Division of Pediatric Emergency Medicine, Texas, USA

E-mail: jeannette.dodson@utsouthwestern.edu ORCID ID: orcid.org/0000-0001-5878-4918

Received/Geliş Tarihi: 20.05.2020 Accepted/Kabul Tarihi: 07.02.2021 


\section{Abstract}

Conclusion: The rates of positive blood culture between febrile and afebrile cohorts presenting to the ED were comparable. While the overall rate of positive culture remains low, consistent with previously reported rates of bacteraemia, an unacceptably high rate of contamination resulting in return visits was observed. Routine blood culture in children who were fully immunised and had a history of febrile illness is not indicated.

Keywords: Fever, paediatric, emergency department, blood culture, contamination

\section{Öz}

hastaların tekrar çağırılması ile sonuçlanan kabul edilemez derecede yüksek bir kontaminasyon oranı gözlemledik. Ateşli hastalık öyküsü olan tam aşılanmış çocuklarda rutin kan kültürü endike değildir.

Anahtar Kelimeler: Ateş, çocuk, acil servis, kan kültürü, kontaminasyon

\section{Introduction}

Blood cultures are frequently obtained from patients who are healthy, have fever and evaluated in the emergency department (ED). Children who are healthy and fully vaccinated often have an identifiable source of infections, such as viral illness, upper respiratory infection, otitis media, enteritis or skin and soft tissue infection. In the past, these patients were at significant risk of developing Streptococcus pneumonia (S. pneumonia) bacteraemia. At present, children who have received the $S$. pneumoniae conjugate vaccine are at low risk of bacteraemia, as the vaccine is $90 \%$ effective. ${ }^{1}$ Additionally, since the 1985 introduction of the Haemophilus influenzae type B (Hib) vaccine in the United States, there continues to be a sustained drop in occult bacteraemia caused by this organism. ${ }^{2,3}$ After the introduction of the 7-valent pneumococcal conjugate vaccine (PCV7), bacteraemia dropped to $0.16-0.37 \%$ in children with fever from 1.6-4.3\%. The rate of S. pneumoniae bacteraemia also decreased to $0.09-0.27 \%$. Furthermore, the introduction of the PCV13 vaccine resulted in a $95.3 \%$ reduction in S. pneumoniae bacteraemia. ${ }^{4}$

Although blood cultures are important for identifying a pathogen to guide therapy, blood culture contamination poses a substantial problem. Blood cultures can be contaminated by inadvertent introduction of native skin or environmental bacteria into the specimen. The accepted benchmark for contamination rates in the hospital setting is approximately $3 \% .^{5}$ A review of peripheral blood cultures showed that contamination rates are highly variable between institutions and can be as high as 9-11\%. ${ }^{5}$ Paediatric blood cultures that become positive because of contamination often result in unnecessary follow-up testing and therapy, since a definitive distinction between pathogen and non-pathogen is not generally available upon clinical re-evaluation. ${ }^{6,7}$

Many studies have attempted to answer how to increase the likelihood of detecting a bacterial pathogen on a blood culture. Aseptic techniques have shown to decrease contamination rates. In addition, some studies have presented that the likelihood of detecting bacterial pathogen on a blood culture is correlated with the volume of blood collected. ${ }^{8-15}$ Other studies have revealed that blood cultures obtained when the patient is febrile increased the likelihood of pathogen-positive bacteraemia. ${ }^{16,17}$ This is due to the presence of intravascular organism causing the release of cytokines, thus resulting in an elevated temperature. However, studies in adults have shown that obtaining the blood culture while the temperature is high did not increase the likelihood of a pathogen-positive blood culture. 18,19 While volume and aseptic techniques for blood culture draws have shown to increase the likelihood of detecting a bacterial pathogen, the utility of fever on presentation to the ED as an independent variable for bacteraemia in paediatric patients who were healthy and fully vaccinated has not been well characterised.

In this study, the primary aim was to describe the diagnosis, disposition, outcome and characteristics of children who were fully vaccinated, previously healthy and febrile from whom bacterial blood cultures were obtained in the ED. The secondary objective was to determine the rate of blood culture contamination and return visits to the ED. The hypothesis was that obtaining blood cultures in children who were healthy, immunocompetent and febrile on presentation to the ED is of low utility.

\section{Materials and Methods}

We conducted a retrospective chart review of all blood cultures collected at children's health ED between January 1, 2015, and December 31, 2015. Our institution is a large tertiary care centre with approximately 180,000 ED visits per year. Approximately five physicians work alongside resident physician, fellow physicians, consultants from all medical and surgical subspecialties, advanced practitioners, nurses and respiratory therapists to provide care for our patients. Patients aged 6 months to 17 years with $>3$ doses of Hib and PCV13 were eligible for enrolment. The exclusion criteria were as follows: incomplete immunisation, immunocompromised 
status, underlying chronic conditions (including sickle cell, splenectomy or functional asplenia, immunodeficiency, asthma and chronic pulmonary insufficiency), ventilator dependence, short-gut syndrome, central venous line and other debilitating diseases. Patients were identified from the ED electronic medical records and microbiology databases to capture any missing data. Demographic, laboratory and outcome data were collected through chart review of enrolled patients. Vaccine history was obtained by parental report at our institution and documented as such within the electronic medical record.

The study was approved by the University of Texas Southwestern Medical Center Institutional Review Board (IRB, STU-012016-075). The requirement to obtain informed consent was waived by the IRB.

At our institution, blood cultures are obtained using standard aseptic technique, including proper hand hygiene, scrubbing the septum of the blood culture bottle using isopropyl alcohol and skin preparation with ChloraPrep ${ }^{\mathrm{TM}}$. Moreover, typically, one set of blood cultures is taken from each patient. An exception would be a patient with a central line; however, these patients were excluded from the study. Blood specimens are placed in the proper blood culture container, specimen bag and bubble wrap zip lock bag. The recommended volume of blood collected for blood cultures is $1 \mathrm{~mL}$ per year of patient age, with a maximum of $10 \mathrm{~mL}$.

Data collected from patients included demographics, initial vital signs, diagnostic tests including complete blood count (CBC) and inflammatory markers, ED disposition, positive blood culture identification and final ED diagnosis. Blood culture results were reviewed and determined to be either a pathogen or likely contaminant. Common contaminants such as coagulase-negative Staphylococcus species (spp.), viridans group Streptococcus spp., diphtheroids, Micrococcus spp., Propionibacterium acnes, Corynebacterium spp. and Bacillus spp. were categorised as such. Blood culture pathogens were defined as any organism not considered a contaminant. Patients were divided into afebrile and febrile cohorts based on the initial temperature on arrival to the ED. Fever was defined as a rectal temperature of $\geq 100.4^{\circ} \mathrm{F}$.

Laboratory tests are often drawn either concomitantly with blood cultures or are used as a screening tool for infection in the ED. The white blood cell (WBC) count measures the number of WBC present, and an elevated WBC may indicate an underlying infection. Normal values for infants and children vary based on age, with higher WBC counts in their first year of life. At our institution, $15.000 / \mathrm{mm}^{3}$ is considered an abnormally elevated WBC. ${ }^{20}$ A Sysmex ${ }^{\mathrm{TM}}$ is used to calculate the WBC at our institution. The C-reactive protein (CRP) is an acute phase reactant, and its levels in the blood serve as a marker for acute inflammation. At our institution, the reference normal interval is $0-1.0 \mathrm{mg} / \mathrm{dL}^{21}$ a Tatellica ${ }^{\mathrm{TM}}$ device is used to calculate the CRP. Laboratory values including CBC and CRP obtained during ED visit were recorded, and values were compared by statistical analysis.

\section{Statistical Analysis}

All statistical analysis for this study was performed by twosample t-test and chi-squared analysis by SPSS ${ }^{\circledR}$ Statistics (Windows version 16, SPSS Inc., Chicago, IL).

\section{Results}

During the study period, 7.980 blood cultures were obtained in the ED, with an overall positivity rate of $5.51 \%(n=440)$. Of these, 6.604 patients with blood cultures drawn met our age criteria and 3.822 patients were excluded after chart review, leaving 2.800 (35\%) patients who were eligible for enrolment (Figure 1). Patients were divided into febrile and afebrile cohorts based on the initial temperature obtained in the ED,

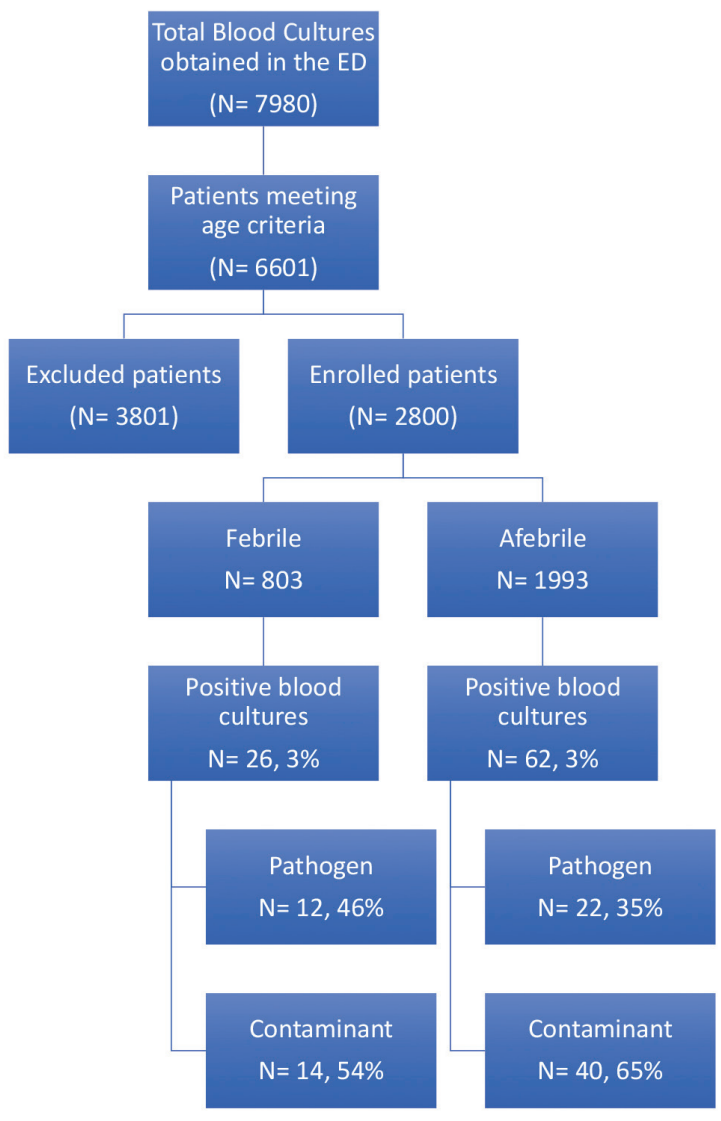

Figure 1. After review, 2.800 patients were eligible for enrolment. Patients were divided into febrile and afebrile cohorts based on initial temperature in the ED. Most bacteria isolated from both cohorts were deemed contaminants ED: Emergency department 
including 1.993 (71\%) patients in the afebrile cohort and 803 (29\%) patients in the febrile cohort.

\section{Demographics}

The median age of the afebrile cohort was 5.17 [standard deviation (SD): 4.98, confidence interval (CI): 4.95-172 5.39] and that of the febrile cohort was 2.86 (SD: $4.45, \mathrm{Cl}: 173$ 2.55-3.17).

The mean age of the afebrile cohort was 6.34 years (SD: 4.98, Cl: 6.12-6.55) and that of the febrile cohort was 4.74 years (SD: $4.45, \mathrm{Cl}: 4.43-5.05)$. The mean age of the afebrile cohort was significantly higher than that of the febrile cohort $(p<0.001)$. Using chi-square analysis, gender was not a significant variable for positive blood culture results $(p=0.07)$ (Table 1).

\section{Laboratory Results}

\section{CBC}

No significant difference $(p=0.17)$ was found between the mean WBC count in the afebrile $\left(12.71\right.$ thousand $/ \mathrm{mm}^{3}$, SD 10.96) and febrile (13.3 thousand $/ \mathrm{mm}^{3}, \mathrm{Cl}: 0.50-12.6, \mathrm{SD}$ : 6.9) cohorts. However, the febrile cohort had more patients with elevated WBC count of 15 thousand $/ \mathrm{mm}^{3}$ or greater than the afebrile cohort $(p=0.001)$. In the afebrile group, the mean WBC count for patients who grew a pathogen (15.2 thousand $/ \mathrm{mm}^{3}, \mathrm{Cl}$ : 9.65-18.73) was significantly higher than that for patients who did not grow a pathogen (12.48 thousand $/ \mathrm{mm}^{3}, \mathrm{Cl}: 12.18-12.78$ thousand $/ \mathrm{mm}^{3}$ ) with $p<0.001$; however, no difference was found in the febrile group $(p=0.08)$ (Table 1$)$.

\section{CRP}

The mean CRP of the febrile cohort $(6.89 \mathrm{mg} / \mathrm{dL}$, SD: 6.84) was significantly higher than that of the afebrile cohort (4.07 mg/dL, Cl: 3.70-4.44, SD: 5.90) as was the ratio of patients with an abnormally elevated CRP $(p<0.001)$. In both groups, the mean CRP for patients who grew a pathogen was significantly higher than that for patients who did not grow an organism (Table 1).

\section{Blood Culture Results}

\section{Afebrile}

Of the 1.993 blood cultures drawn in the afebrile cohort, $1.931(97 \%)$ blood cultures did not grow an organism after 5 days of incubation. Of the remaining 62 (3\%) blood cultures that grew an organism, 40 (65\%) were contaminants and 22 (35\%) were pathogens.

\section{Febrile}

Of the 803 blood cultures drawn in the febrile cohort, 777 (97\%) blood cultures did not grow an organism after 5 days of incubation. Of the remaining 26 (3\%) blood cultures that grew an organism, 14 (54\%) cultures were contaminants and $12(46 \%)$ were pathogens. Contaminants and pathogens grown from the afebrile and febrile cohorts are presented in Tables 2 and 3, respectively.

The overall positive blood culture rate for true pathogens was $1.3 \%$, and the overall contamination rate was $1.9 \%$. For both cohorts, the most common sources of pathogenic bacteraemia were Escherichia coli (pyelonephritis), $H$.

\section{Table 1. Demographics and laboratory values: A comparison between afebrile and febrile cohorts}

\begin{tabular}{|c|c|c|c|}
\hline Variable & Afebrile & Febrile & $\mathbf{p}$ \\
\hline Male & $1.076(54 \%)$ & $403(50 \%)$ & 0.07 \\
\hline Female & $915(46 \%)$ & $400(50 \%)$ & 0.07 \\
\hline Mean CRP negative blood culture & 3.94 & 6.64 & - \\
\hline CRP $f 1.0$ & $412(42 \%)$ & $49(17 \%)$ & - \\
\hline CRP $>1.0$ & $578(58 \%)$ & $240(83 \%)$ & $<0.001$ \\
\hline Mean WBC pathogen & 15.2 & 14.01 & - \\
\hline Mean WBC contaminant & 13.30 & 16.32 & - \\
\hline Mean WBC negative blood culture & 12.48 & 13.25 & - \\
\hline WBC 0.0-4.9 & $96(5 \%)$ & $46(6 \%)$ & - \\
\hline
\end{tabular}


influenzae (pneumonia), methicillin-resistant $S$. aureus (septic arthritis, osteomyelitis and cellulitis), oxicillin-sensitive $S$. aureus (osteomyelitis), Salmonella typhi (typhoid fever), $S$. pneumoniae (cellulitis, osteomyelitis and pneumonia) and $S$.

Table 2. Comparison of contaminants between afebrile and febrile cohorts ( $n=54,1.9 \%$ of total cultures drawn)

\begin{tabular}{|lll|}
\hline Contaminant & Afebrile & Febrile \\
\hline Actinomyces spp. & 2 & 0 \\
\hline Anthrobacter spp. & 1 & 0 \\
Bacillus spp. & 4 & 2 \\
Bipolaris spp. & 1 & 0 \\
Coagulase-negative Staphylococcus spp. & 18 & 7 \\
\hline Environmental Gram-negative rod & 1 & 0 \\
Granulicatella spp. & 2 & 0 \\
Lactococcus spp. & 1 & 0 \\
Micrococcus spp. & 0 & 2 \\
\hline Moraxella spp. & 1 & 0 \\
Pseudomonas oryzihabitans & 1 & 0 \\
Streptococcus constellatus and Eikenella spp. & 0 & 1 \\
Viridans group Streptococcus spp. & 8 & 2 \\
\hline Total & 40 & 14 \\
\hline
\end{tabular}

pyogenes (cellulitis and abscess) (Table 3). Using chi-square analysis, positive blood culture results showed no significant difference between the afebrile and febrile cohorts $(p=0.86)$. Likewise, no significant difference was found in the number of blood cultures positive for a pathogen between the two cohorts $(p=0.35)$ (Table 4).

\section{Disposition}

In the afebrile cohort, 523 (26\%) patients were admitted and $1.470(74 \%)$ were discharged. Among patients who were admitted, 78 (15\%) were admitted to the intensive care medicine (ICU). Among patients who were discharged, 89 (6\%) were readmitted to the ED within $48 \mathrm{~h}$ for on-going or worsening symptoms, positive blood culture results or a new complaint. Among the 89 patients who were readmitted, 19 $(1.3 \%)$ were called back due to positive blood culture results. All 19 patients had a repeated blood culture drawn on their second ED visit. Of these patients, 3 (16\%) had positive blood cultures that grew the same pathogen isolated in the initial blood culture. None of the patients had repeated blood cultures classified as a contaminant.

In the febrile cohort, 236 (29\%) patients were admitted and 567 (71\%) were discharged. Among the patients who

\begin{tabular}{|llll|}
\hline \multicolumn{4}{l}{ Table 3. Comparison of pathogenic bacteria between afebrile and febrile cohorts } \\
\hline Pathogen & Afebrile & Febrile & Final diagnosis \\
\hline Escherichia coli & 2 & 2 & Pyelonephritis (3), appendicitis (1) \\
Haemophilus influenzae & 0 & 1 & Pneumonia (1) \\
Methicillin-resistant Staphylococcus aureus & 4 & 4 & $\begin{array}{l}\text { Septic arthritis (4), cellulitis/abscess (2), osteomyelitis } \\
(1) \text {, positive blood culture call back (1) }\end{array}$ \\
\hline Oxicillin-sensitive S. aureus & 10 & 3 & $\begin{array}{l}\text { Osteomyelitis (11), lymphadenitis (1), septic arthritis } \\
(1)\end{array}$ \\
\hline Salmonella typhi & 1 & 0 & Typhoid fever (1) \\
\hline $\begin{array}{l}\text { Streptococcus pneumoniae } \\
\text { Streptococcus pyogenes }\end{array}$ & 4 & 1 & Septic arthritis, cardiac arrest, pneumonia \\
\hline Total & 1 & 1 & Abscess/cellulitis (2) \\
\hline
\end{tabular}

Table 4. Blood culture results and disposition: a comparison between afebrile and febrile cohorts

\begin{tabular}{|llll|}
\hline Variable & Afebrile & Febrile & p \\
\hline Mean temperature (fahrenheit) & 98.5 & 101.9 & $<0.001$ \\
\hline Total blood culture & 1.993 & 803 & - \\
\hline Negative blood culture & $1.931(97 \%)$ & $777(97 \%)$ & - \\
\hline Positive blood culture & $62(3 \%)$ & $26(3 \%)$ & 0.86 \\
\hline Contaminants & $40(65 \%)$ & $14(54 \%)$ & - \\
\hline Pathogens & $22(35 \%)$ & $12(46 \%)$ & 0.35 \\
\hline Admitted & $523(26 \%)$ & $236(29 \%)$ & 0.09 \\
\hline Discharged & $1.470(74 \%)$ & $567(71 \%)$ & - \\
\hline Readmitted & $89(6 \%)$ & $33(6 \%)$ & - \\
\hline Call back & $19(1.3 \%)$ & $6(1 \%)$ & - \\
\hline Call back pathogen & $3(16 \%)$ & $2(33 \%)$ & 0.35 \\
\hline
\end{tabular}


were admitted, 36 (15\%) were admitted to the ICU; no deaths occurred. Of the patients who were discharged, 33 (6\%) returned to the ED within $48 \mathrm{~h}$. Among patients who returned to the ED, $6(1 \%)$ were called back for positive blood culture results, and of these, 2 (33\%) grew the same organism isolated in the initial blood culture.

Obtaining a blood culture did not significantly affect the admission of patients between the afebrile and febrile cohorts ( $p=0.09$ ). Admission rates to the ICU for both cohorts were the same, and three deaths occurred in this group. Furthermore, although patients were called back for positive blood cultures, fever on presentation did not increase the likelihood of isolating a pathogenic organism on repeated blood culture ( $p=0.35$ ) (Table 4). Most culture-positive isolates were deemed likely contaminants, and they were never isolated a second time on the repeated culture. Moreover, $16(40 \%)$ of the 40 patients who grew a contaminant were called back for positive blood cultures, of which $8(20 \%)$ were admitted pending repeated culture results and antibiotics.

\section{Discussion}

Blood cultures are frequently drawn from otherwise healthy paediatric patients who present to the ED, despite established evidence that there is a sustained decrease in the incidence of bacteraemia in these patients after the advent of the S. pneumoniae conjugate and Hib vaccines. ${ }^{1-3}$ One of the common reasons to draw blood cultures is a history of fever or presence of fever in the ED in the absence of an identifiable source. However, the utility of obtaining blood cultures from these patients who are otherwise healthy, fully vaccinated and aged $>6$ months has not been well characterised. No current evidence has supported this practice in a well-appearing child even in the presence of other bacterial infections such as a urinary tract infection, ${ }^{22}$ pneumonia ${ }^{23}$ or skin and soft tissue infections. ${ }^{24}$ In this study, we demonstrated that in children who are healthy, fully vaccinated and aged >six months, the likelihood of bacteraemia was low. Of the 7.980 patients from whom blood cultures were drawn in 2015, 34 grew a true pathogen $(0.4 \%)$. This reflects that the majority of blood cultures drawn from children were largely uninformative, and we can question the utility of these blood cultures.

Although our overall contamination rate was relatively low (1.9\%) compared with the national benchmark of $3 \%$, our study showed that if a blood culture was positive, it was more likely to be a contaminant than a pathogen. Blood culture contamination may result in hospital admission and unnecessary antibiotic therapy, thereby increasing risk of bacterial resistance and acquisition of hospital-acquired infections. Furthermore, patients who have been discharged must be contacted for follow-up evaluation. If they are unreachable, they must be found with the use of outside resources, including at times police officers.

Our study highlights that as many as $40 \%$ of the patients who grew a contaminant were called back because of a positive blood culture result and 20\% were admitted pending blood culture results and antibiotics. A 2018 retrospective study by Hall et al. ${ }^{5}$ highlighted the financial burden associated with each blood culture contaminant including additional hospital admission days, antibiotic use, additional laboratory testing, radiography and procedures. This does not include internal or external resources used to locate children with blood culture contaminants for re-evaluation or non-hospital associated strain for family such as the time that families must spend in the hospital and the emotional stresses on the families of finding additional child care, missing work or general apprehension about the health of their child. Although the overall contamination rate at our institution was relatively low, the rates of some institutions can be as high as $11 \%$, making the ratio of pathogen to contaminants even more disparate and the overall burden to the healthcare system and families even more elevated.

In the United States, an increasing emphasis has been placed on value-driven healthcare, leading to an objective to achieve better quality cost-effective outcomes. ${ }^{25}$ Several institutions have developed measures to aid in reducing cost without compromising the quality of the healthcare delivered. The Rochester, ${ }^{26}$ Philadelphia ${ }^{27}$ and Boston ${ }^{28}$ criteria each identify children with febrile condition at low risk for bacteraemia, thereby reducing unnecessary admissions in otherwise healthy children. In 2008, published guidelines stated that the reduced risk of bacteraemia in children who have received Hib and PCV7 vaccines makes screening with WBC count unnecessary. ${ }^{1}$ Despite evidence that contradicts obtaining blood cultures or labs such as a WBC count in healthy children, our study highlights that providers may still routinely obtain blood cultures in this population.

Our study has shown that gender is not a significant variable for predicting bacteraemia. However, the mean age of the afebrile cohort was significantly higher than that of the febrile cohort. Although the age of the febrile cohort was significantly lower than that of the afebrile cohort, those febrile did not have a significantly higher admission rate or significant difference in the positivity rate of blood cultures for pathogenic bacteria. This further supports the argument that age and gender should not be driving factors in children aged $>6$ months who have received complete vaccinations.

Laboratory tests such as WBC count or CRP are often used as ancillary or screening tests to determine the risk of bacteraemia. Previous studies have shown that an elevated WBC is a better marker of bacteraemia than fever alone. ${ }^{29,30}$ 
In our study, we compared WBC count among patients with febrile and afebrile condition on ED presentation. Despite elevated WBC counts among patients with febrile condition, no significant difference was found in the WBC counts between patients with true pathogen versus negative culture, suggesting that WBC count is a poor indicator of bacteraemia. However, a slightly elevated mean CRP was observed, although significant. This finding is consistent with previous studies suggesting that CRP can provide value in predicting bacteraemia in children with fever.

Our results show that among patients who have blood cultures drawn, 73\% were discharged home. Furthermore, among patients who were discharged and called back owing to a positive blood culture result, the likelihood of the organism being a pathogen was low, as the repeat blood culture was more likely to be negative or the organism is a contaminant. A febrile status on initial presentation to the ED did not significantly predict the likelihood of admission. However, the difference between the afebrile and febrile cohorts was nearly significant, suggesting that patients who were febrile on presentation may have a higher likelihood for admission due to other clinical findings.

\section{Study Limitations}

This study is limited to the information obtained as a retrospective chart review. As such, physical examination documentation including general condition of the patient on arrival to the ED and other pathological findings were variable and difficult to ascertain. Likewise, we had to rely on parental report for vaccines, which may be subjected to recall bias. Although the best practice for obtaining blood cultures is advised, there may be individual variability when obtaining blood cultures in terms of using the aseptic technique and volume of blood drawn for blood culture. This could influence the rate of contamination or yield of pathogen-positive blood cultures. We did not account for differences in WBC values based on age. However, considering age in the analysis could change the results of this study. This study was conducted at a single centre, which may have different clinical practices when compared with other centres. This extends to patients' characteristics, likelihood to do testing (i.e. WBC, CRP and blood cultures) and likelihood of prevalence of finding the outcome of pathogenic bacteraemia which may hinder generalisability.

\section{Conclusion}

Overall, the utility of obtaining blood cultures in patients aged $>6$ months, fully vaccinated and otherwise healthy is low. The benefit of blood cultures drawn from this population does not outweigh the drawbacks for incurring a blood culture contaminant including the potential for costly admissions, exposure to unnecessary antibiotics and stress for their families with the caveat that the condition of the patient is not unstable or appearing toxic. Owing to the retrospective nature of this study, the general condition of the patient was not accounted for. This must be taken into consideration, as a child who is toxic appearing or has unstable condition must be evaluated for sepsis. A quality improvement process to reduce the frequency of blood cultures from well children and to reduce the rate of contamination should be considered.

\section{Ethics}

Ethics Committee Approval: The study was approved by the University of Texas Southwestern Medical Center Institutional Review Board (IRB, STU-012016-075).

Informed Consent: The requirement to obtain informed consent was waived by the IRB.

Peer-review: Externally peer-reviewed.

\section{Authorship Contributions}

Concept: J.D., H.H., Design: M.B., E.M.., Analysis or Interpretation: J.D., H.H., Writing: J.D., H.H., M.B., M.T.

Conflict of Interest: No conflict of interest was declared by the authors.

Financial Disclosure: The authors declared that this study received no financial support.

\section{References}

1. Baraff LJ. Management of fever without source in infants and children. Ann Emerg Med. 2000;36:602-14

2. Alpern ER, Alessandrini EA, Bell LM, Shaw KN, McGowan KL. Occult bacteremia from a pediatric emergency department: current prevalence, time to detection, and outcome. Pediatrics. 2000;106:505-11.

3. Bandyopadhyay S, Bergholte J, Blackwell CD, Friedlander JR, Hennes $\mathrm{H}$. Risk of serious bacterial infection in children with fever without a source in the post-Haemophilus influenzae era when antibiotics are reserved for culture-proven bacteremia. Arch Pediatr Adolesc Med. 2002;156:512-7.

4. Greenhow TL, Hung YY, Herz A. Bacteremia in Children 3 to 36 Months Old After Introduction of Conjugated Pneumococcal Vaccines. Pediatrics. 2017;139:20162098.

5. Hall RT, Domenico HJ, Self WH, Hain PD. Reducing the blood culture contamination rate in a pediatric emergency department and subsequent cost savings. Pediatrics. 2013;131:292-7.

6. Rowley $A H$, Wald ER. The incubation period necessary for detection of bacteremia in immunocompetent children with fever. Implications for the clinician. Clin Pediatr (Phila). 1986;25:485-9.

7. Waltzman ML, Harper M. Financial and clinical impact of falsepositive blood culture results. Clin Infect Dis. 2001;33:296-9.

8. Arpi M, Bentzon MW, Jensen J, Frederiksen W. Importance of blood volume cultured in the detection of bacteremia. Eur J Clin Microbiol Infect Dis. 1989;8:838-42 
9. Hall MM, Ilstrup DM, Washington JA 2nd. Effect of volume of blood cultured on detection of bacteremia. J Clin Microbiol. 1976;3:643-5.

10. Hall KK, Lyman JA. Updated review of blood culture contamination. Clin Microbiol Rev. 2006;19:788-802.

11. Ilstrup DM, Washington JA 2nd. The importance of volume of blood cultured in the detection of bacteremia and fungemia. Diagn Microbiol Infect Dis. 1983;1:107-10.

12. Lee A, Mirrett S, Reller LB, Weinstein MP. Detection of bloodstream infections in adults: how many blood cultures are needed? J Clin Microbiol. 2007;45:3546-8

13. Mermel LA, Maki DG. Detection of bacteremia in adults: consequences of culturing an inadequate volume of blood. Ann Intern Med. 1993;119:270-2.

14. Reimer LG, Wilson ML, Weinstein MP. Update on detection of bacteremia and fungemia. Clin Microbiol Rev. 1997;10:444-65.

15. Tenney JH, Reller LB, Mirrett S, Wang WL, Weinstein MP. Controlled evaluation of the volume of blood cultured in detection of bacteremia and fungemia. J Clin Microbiol. 1982;15:558-61.

16. Weinstein MP, Murphy JR, Reller LB, Lichtenstein KA. The clinical significance of positive blood cultures: a comprehensive analysis of 500 episodes of bacteremia and fungemia in adults. II. Clinical observations, with special reference to factors influencing prognosis. Rev Infect Dis. 1983;5:54-70.

17. Bryan CS. Clinical implications of positive blood cultures. Clin Microbiol Rev. 1989;2:329-53.

18. Riedel S, Bourbeau P, Swartz B, Brecher S, Carroll KC, et al. Timing of specimen collection for blood cultures from febrile patients with bacteremia. J Clin Microbiol. 2008;46:1381-5.

19. Jaimes F, Arango C, Ruiz G, Cuervo J, Botero J, et al. Predicting bacteremia at the bedside. Clin Infect Dis. 2004;38:357-62.
20. Soldin SJ, Wong EC, Brugnara C, Solden OP. American Association for Clinical Chemistry. Pediatric reference intervals. 7th ed. American Association for Clinical Chemistry; 2011:304.

21. N.W. T. Clinical Guide on Laboratory Tests. 3rd ed. WB Saunders, Philadelphia, PA. 1995.

22. Pitetti RD, Choi S. Utility of blood cultures in febrile children with UTI. Am J Emerg Med. 2002;20:271-4.

23. Shah SS, Dugan MH, Bell LM, Grundmeier RW, Florin TA, et al. Blood cultures in the emergency department evaluation of childhood pneumonia. Pediatr Infect Dis J. 2011;30:475-9.

24. Malone JR, Durica SR, Thompson DM, Bogie A, Naifeh M. Blood cultures in the evaluation of uncomplicated skin and soft tissue infections. Pediatrics. 2013;132:454-9.

25. Conway PH. Value-driven health care: implications for hospitals and hospitalists. J Hosp Med. 2009;4:507-11.

26. Jaskiewicz JA, McCarthy CA, Richardson AC, White $K C$, Fisher $D$, et al. Febrile infants at low risk for serious bacterial infection-an appraisal of the Rochester criteria and implications for management. Febrile Infant Collaborative Study Group. Pediatrics. 1994;94:390-6.

27. Baker MD, Bell LM, Avner JR. Outpatient management without antibiotics of fever in selected infants. N Engl J Med. 1993;329:1437-41.

28. Baskin MN, O'Rourke EJ, Fleisher GR. Outpatient treatment of febrile infants 28 to 89 days of age with intramuscular administration of ceftriaxone. J Pediatr. 1992;120:22-7.

29. Jaffe DM, Fleisher GR. Temperature and total white blood cell count as indicators of bacteremia. Pediatrics. 1991;87:670-4.

30. Isaacman DJ, Shults J, Gross TK, Davis PH, Harper M. Predictors of bacteremia in febrile children 3 to 36 months of age. Pediatrics. 2000;106:977-82 